JIIA, VOLUME 8 No 2, MEI 2020

\title{
PENDAPATAN DAN TINGKAT KESEJAHTERAAN \\ RUMAH TANGGA PERTANIAN DI KELURAHAN KEDAUNG KECAMATAN KEMILING KOTA BANDAR LAMPUNG
}

\author{
(Income and Welfare Analyses of Households in Agriculture in Kedaung of Kemiling District of \\ Bandar Lampung City)
}

\author{
Wernat Newell Simamora, Wan Abbas Zakaria, Eka Kasymir
}

Jurusan Agribisnis, Fakultas Pertanian, Universitas Lampung, Jl. Prof. Dr. Soemantri Brojonegoro No.1 Bandar Lampung 35141, Telp +62822 7936 6942, e-mail: wanabas.zakaria@fp.unila.ac.id

\begin{abstract}
The purpose of this study was to analyze the main farming income, annual household income, welfare, and factors that influence the level of household welfare. Data were collected in June-August 2018. The research location was determined intentionally because the Kedaung Village was one of the regions with high poverty levels in the Kemiling District of Bandar Lampung City. The number of respondents in this study was 40 respondents taken using simple random sampling technique. The analytical methods used were farm income analysis, household income analysis, and welfare level analysis. The results of the study explained that the average main farming income was differentiated based on two cropping patterns, namely: first cropping pattern (beans - beans) amounting to Rp2,537,872.35/0,08 ha per year, while in the second cropping pattern (beans - long beans) amounting to Rp2,830,339.88/0,07ha per year. The average household income every year based on cropping patterns was Rp23,317,784.40 per year of the first cropping pattern and Rp13,841,450.10 per year of the second cropping pattern. As many as 95 percent of agricultural households in Kedaung Sub-District, Kemiling District, Bandar Lampung City are in the category of unprosperous. This situation occurs because of low social, educational, and health scores.
\end{abstract}

Keywords: agriculture household, income, welfare indicators

\section{PENDAHULUAN}

Pembangunan nasional bertujuan untuk meningkatkan perekonomian agar mampu menciptakan lapangan pekerjaan dan menata kehidupan yang lebih baik bagi masyarakat Salah satu tujuan pembangunan nasional adalah menurunkan angka kemiskinan.

Kemiskinan menjadi permasalahan yang kompleks sehingga pengentasan kemiskinan harus dilakukan dengan mencakup berbagai aspek kehidupan masyarakat yang kemudian dilaksanakan secara terpadu karena bersifat multidimensional. Kemiskinan dipandang sebagai ketidakmampuan dari sisi ekonomi untuk memenuhi kebutuhan dasar makanan dan bukan makanan yang diukur dari sisi pengeluaran (BPS 2014).

Pulau Sumatera, memiliki tingkat kepadatan penduduk kedua setelah Pulau Jawa. Provinsi Lampung menjadi provinsi dengan jumlah penduduk miskin terbanyak ketiga, padahal Provinsi Lampung ini merupakan pintu gerbang yang menjadi jalur darat perekonomian dari Pulau Jawa menuju wilayah-wilayah di Pulau Sumatera.
Provinsi Lampung memiliki 13 kabupaten dan dua kota madya dengan jumlah penduduk miskin di Kota Bandar Lampung sebanyak 100.500 jiwa. Kecamatan Kemiling menjadi kecamatan dengan tingkat kemiskinan tertinggi di Kota Bandar Lampung dengan jumlah penduduk miskin sebesar 10.928 jiwa (BPS 2017).

Berkembangnya Kota Bandar Lampung dan meningkatnya pertumbuhan penduduk menjadikan Kecamatan Kemiling memberikan akses yang baik sehingga menyebabkan berkurangnya lahan pertanian. Kelurahan Kedaung merupakan salah satu dari sembilan kelurahan di Kecamatan Kemiling yang masih memiliki lahan pertanian dan mayoritas masyarakatnya bekerja di bidang pertanian. Terdapat 1.362 kepala keluarga yang tinggal di Kelurahan Kedaung dengan jumlah 173 penduduk miskin (BPS 2016).

Kondisi sosial masyarakat tersebut menarik perhatian untuk dilakukan kajian agar diperoleh informasi mengenai tingkat pendapatan usahatani utama, pendapatan rumah tangga pertahun dan tingkat kesejahteraan. Melalui penelitian ini, 
diharapkan diperoleh informasi yang dapat dijadikan bahan pertimbangan bagi para pengambil kebijakan terkait dengan upaya peningkatan taraf hidup petani di wilayah peri urban.

\section{METODE PENELITIAN}

Penelitian dilakukan di Kelurahan Kedaung Kecamatan Kemiling Kota Bandar Lampung yang memiliki populasi penduduk miskin sebanyak 173 kepala keluarga dengan menggunakan metode survei. Penentuan lokasi dipilih secara sengaja, yaitu Lingkungan 2 Kelurahan Kedaung dengan pertimbangan bahwa daerah tersebut memiliki jumlah penduduk miskin terbanyak dengan mayoritas penduduk bekerja sebagai petani. Pengambilan data dilakukan pada bulan Juni- Juli 2018. Jumlah responden diperoleh berdasarkan formula Sugiarto, dkk (2003) yaitu:

$$
\mathrm{n}=\frac{\mathrm{NZ}^{2} \mathrm{~S}^{2}}{\mathrm{~N}^{2}+\mathrm{Z}^{2} \mathrm{~S}^{2}}
$$

Keterangan :

$\mathrm{n}=$ Ukuran sampel

$\mathrm{N}=$ Ukuran populasi (173kk)

$\mathrm{Z}=$ Derajat kepercayaan $\mathrm{Z}(90 \%=1,645)$

$\mathrm{S}^{2}=$ Varian sampel $(5 \%=0,05)$

$\mathrm{d}=$ Standar deviasi $(5 \%=0,05)$

Berdasarkan persamaan satu diperoleh sampel sebanyak 40 responden. Pemelihan responden ditentukan dengan teknik simple random sampling yaitu penentuan sampel dengan sederhana yang dilakukan secara acak tanpa memperhatikan strata atau kriteria yang ada dalam populasi tersebut (Sugiyono 2010). Menururt Soekartawi (1994), untuk mengetahui pendapatan dari usahatani dapat dihitung dengan rumus sebagai berikut:

$\pi=\mathrm{YPy}-\Sigma \mathrm{XiPXi}$

Keterangan:

$\pi=$ Keuntungan

$\mathrm{Y}=$ Produksi

Py $=$ Harga produksi

$\mathrm{Xi}=$ Faktor produksi

$\mathrm{i}=1,2,3,4, \ldots . ., \mathrm{n}$

Pxi $=$ Harga faktor produksi

Penghitungan pendapatan rumah tangga diperoleh dengan dengan rumus sebagai berikut:

$\mathrm{Prt}=\mathrm{P}$ onfarm $+\mathrm{P}$ off farm $+\mathrm{P}$ non farm $\ldots .$.
Keterangan:

Prt $=$ Pendapatan rumah tangga

$\mathrm{P}$ onfarm = Pendapatan dari usahatani

$\mathrm{P}$ offfarm = Pendapatan dari luar usahatani

P non farm $=$ Pendapatan non pertanian

Pengukuran tingkat kesejahteraan petani menggunakan tujuh indikator BPS (2014) meliputi kependudukan, kesehatan dan gizi, pendidikan, ketenagakerjaan, taraf dan pola konsumsi, perumahan dan lingkungan, sosial dan lain-lain.

$$
R S=\frac{S k T-S k R}{j k i} \ldots \ldots \ldots \ldots \ldots \ldots \ldots
$$

Keterangan :

$\mathrm{RS}=$ Range skor

SkT $=$ Skor tertinggi $(7 \times 3=21)$

$\mathrm{SkR}=$ Skor terendah $(7 \mathrm{x} 1=7)$

7 = Jumlah indikator kesejahteraan BPS

$3=$ Skor tertinggi dalam indikator BPS

$2=$ Skor sedang dalam indikator BPS

$1=$ Skor terendah dalam indikator BPS

\section{HASIL DAN PEMBAHASAN}

\section{Gambaran Umum}

Hasil penelitian menjelaskan usia rata-rata responden adalah 53 tahun dengan rentang usia 3071 tahun. Usia produktif menentukan tingkat usaha, semangat, dan kemampuan dalam mengembangkan usahatani cenderung lebih tinggi dan memiliki tanggung jawab yang besar (Mantra 2003).

Pendidikan petani tergolong rendah dengan hasil rata-rata 57,5 persen pendidikan akhir pada di tingkat Sekolah Dasar. Petani hanya mempertimbangkan pengalaman untuk dapat mengelola usahatani dengan hasil persentase sebesar 65 persen petani memiliki pengalaman dengan rentang waktu 23-30 tahun dalam berusahatani.

Kemiskinan erat kaitannya dengan jumlah anggota keluarga yang menggambarkan jumlah tanggungan kepala rumah tangga. Rata-rata jumlah tanggungan keluarga pada petani di Kelurahan Kedaung, Kecamatan Kemiling, Kota Bandar Lampung adalah sebanyak empat orang dari seluruh responden. 


\section{Keragaan Usahatani}

Identifikasi terhadap keragaan usahatani perlu diketahui untuk melihat aktivitas usahatani. Berdasarkan hasil penelitian, dari total 40 responden terdapat dua jenis pola tanam yang di lakukan, yaitu: Pola Tanam I (buncis-buncis) sebanyak 31 responden dan Pola Tanam II (buncis-kacang panjang) sebanyak sembilan responden.

\section{Pola Tanam I (Buncis - Buncis)}

Pola tanam I dimulai pada bulan SetemberNovember (musim tanam I) dengan budidaya tanaman buncis. Setelah selesai, petani melanjutkan penanaman pada lahan yang sama dengan jenis tanaman yang sama pada bulan Desember-Maret (musim tanam II). Saat musim kemarau dengan sedikit curah hujan (AprilAgustus) petani membiarkan lahan tidak ditanami dengan tujuan meningkatkan daya dukung tanah ketika akan memulai musim tanam. Penggunaan sarana dan biaya produksi pada pola tanam I disajikan pada Tabel 1.

Benih menjadi faktor yang penting dalam budidaya usahatani, karena mempengaruhi produksi yang dihasilkan. Varietas benih buncis yang digunakan adalah varietas merambat sehingga dibutuhkan media perambat tanaman untuk tanaman dapat tumbuh dengan baik. Jenis benih diperbanyak dengan biji yang diseleksi dari tanaman sehat dan subur. Benih yang telah diseleksi dari hasil produksi terbaik akan disimpan kedalam botol

Tabel 1. Penggunaan sarana dan biaya produksi (Pola tanam I musim tanam I).

\begin{tabular}{lrrr}
\hline \multirow{2}{*}{ Uraian } & \multicolumn{3}{c}{ Musim Tanam I } \\
\cline { 2 - 4 } & Jumlah & \multicolumn{1}{c}{ Harga } & \multicolumn{1}{c}{ Biaya } \\
\hline Benih & 2,47 & $14.200,00$ & $35.110,65$ \\
Pupuk: & & & \\
$\quad$ Kandang (tunai) & 366,92 & 703,23 & $258.029,78$ \\
Kandang (non tunai) & 345,56 & 703,23 & $243.003,58$ \\
Urea & 17,00 & $2.903,23$ & $49.354,84$ \\
Phonska & 16,35 & $2.551,61$ & $41.731,22$ \\
\hline Pestisida: & & & \\
Suprasit & 0,11 & $193.548,39$ & $21.852,24$ \\
Sidametrin & 0,10 & $254.193,55$ & $24.599,38$ \\
Curakron & 0,08 & $286.129,03$ & $22.151,93$ \\
\hline Peralatan: & & & \\
Golok & & & $14.032,26$ \\
Cangkul & & & $19.032,26$ \\
Gembor & & & $18.750,00$ \\
Sprayer & & & $12.225,81$ \\
Lanjaran bambu & & & $31.462,37$ \\
Arit & & & $2.709,68$ \\
\hline
\end{tabular}

Tabel 2. Penggunaan sarana dan biaya produksi (Pola tanam I musim tanam II).

\begin{tabular}{lrrr}
\hline \multirow{2}{*}{ Uraian } & \multicolumn{3}{c}{ Musim Tanam II } \\
\cline { 2 - 4 } & Jumlah & \multicolumn{1}{c}{ Harga } & \multicolumn{1}{c}{ Biaya } \\
\hline Benih & 2,28 & $14.200,00$ & $32.305,00$ \\
Pupuk: & & & \\
Kandang (tunai) & 354,55 & 675,00 & $239.318,18$ \\
Kandang (non tunai) & 371,76 & 675,00 & $250.941,18$ \\
Urea & 16,79 & $3.000,00$ & $50.357,14$ \\
Phonska & 16,29 & $2.564,29$ & $41.761,22$ \\
\hline Pestisida: & & & \\
Suprasit & 0,10 & $209.285,71$ & $20.928,57$ \\
Sidametrin & 0,09 & $246.428,57$ & $22.882,65$ \\
Curakron & 0,09 & $286.785,71$ & $26.630,10$ \\
\hline Peralatan: & & & \\
$\quad$ Golok & & & $14.032,26$ \\
Cangkul & & & $19.032,26$ \\
Gembor & & & $18.750,00$ \\
Sprayer & & & $12.225,81$ \\
Lanjaran bambu & & & $31.462,37$ \\
Arit & & & $2.709,68$ \\
\hline
\end{tabular}

yang dapat bertahan hingga enam bulan. Dalam satu botol, berat benih berkisar $0,35 \mathrm{~kg}$. Harga benih buncis yang terdapat di lokasi penelitian Rp140.000,00/kg. Biaya penggunaan benih musim tanam I sebesar Rp35.110,65/0,08 ha dan musim tanam II Rp32.305,00. Penggunaan sarana dan biaya produksi (Pola tanam I musim tanam I) tersaji pada Tabel 1

Pupuk juga menjadi faktor produksi yang penting dalam usahatani. Pupuk merupakan bahan-bahan (organik atau anorganik) yang diberikan pada tanah untuk memperbaiki keadaan fisik tanah dan melengkapi kebutuhan tanaman.

Penggunaan pupuk oleh responden di Kelurahan Kedaung jumlahnya berbeda-beda. Pupuk yang digunakan adalah pupuk urea, pupuk phonska dan pupuk kandang. Sebagian besar responden memiliki usaha ternak yang dapat dimanfaatkan limbahnya sebagai pupuk, sehingga penggunaan pupuk kandang dibedakan atas biaya tunai dan biaya diperhitungkan. Jumlah biaya tunai pupuk yang dikeluarkan pada musim tanam I adalah Rp349.115,84 sedangkan pada musim tanam II adalah Rp331.436,54. Penggunaan pestisida dalam usahatani umumnya bertujuan untuk mengendalikan serangan gulma, hama, dan penyakit. Penggunaan pestisida dilakukan dengan melihat kondisi tanaman, melalui luasan hama dan penyakit yang menyerang tanaman. Merek dagang pestisida yang digunakan petani pada masingmasing pola tanam hampir sama, yaitu: sidametrin, curakron dan suprasit dengan harga yang diperoleh dari lokasi penelitian 
Tabel 3. Penggunaan tenaga kerja pada musim tanam I dan II pola tanam I.

\begin{tabular}{lcccccc}
\hline \multirow{2}{*}{ Jenis Kegiatan } & \multicolumn{6}{c}{ Pola Tanam I } \\
\cline { 2 - 7 } & \multicolumn{3}{c}{ MT I } & \multicolumn{4}{c}{ MT II } \\
\cline { 2 - 7 } & DK & LK & Total & DK & LK & Total \\
\hline Pengolahan lahan & 2,65 & 2,72 & 5,38 & 2,28 & 2,17 & 4,44 \\
Penanaman benih & 1,03 & 0,00 & 1,03 & 1,00 & 0,00 & 1,00 \\
Pemupukan & 0,88 & 0,00 & 0,88 & 0,83 & 0,00 & 0,83 \\
Penyulaman & 1,65 & 0,00 & 1,65 & 1,56 & 0,00 & 1,56 \\
Penyiangan gulma & 1,41 & 0,00 & 1,41 & 1,38 & 0,00 & 1,38 \\
Pengendalian HPT & 1,87 & 0,00 & 1,87 & 1,47 & 0,00 & 1,47 \\
Panen & 3,88 & 0,63 & 4,51 & 2,55 & 0,70 & 3,25 \\
Pasca Panen & 1,54 & 0,00 & 1,54 & 1,15 & 0,00 & 1,15 \\
\hline Jumlah & 14,91 & 3,35 & 18,26 & 12,21 & 2,86 & 15,08 \\
\hline
\end{tabular}

berkisar antara Rp15.000,00-Rp30.000,00. Total biaya pestisida musim tanam I adalah Rp68.603,55 sedangkan pada musim tanam II adalah sebesar Rp70.441,32.

Biaya yang harus dikeluarkan pada tenaga kerja usahatani adalah biaya pengolahan lahan, penanaman, pemupukan, penyulaman, penyiangan gulma, pengendalian hama, panen dan pasca panen. Biaya tenaga kerja banyak tercurah pada proses pengolahan lahan dengan total musim tanam I sebesar 5,38 HKP dan musim tanam II sebesar 4,44 HKP. Keseluruhan penggunaan tenaga kerja pada pola tanam I dapat dilihat pada Tabel 3.

Produksi terbesar selama enam kali panen di musim tanam I diperoleh pada panen kedua sebesar 110,16kg dengan harga Rp4.403,23/kg dan terendah sebesar $30,63 \mathrm{~kg}$ dengan harga $\mathrm{Rp} 4.730,77 / \mathrm{kg}$. Total produksi pada musim tanam I sebesar 431,61kg dengan harga Rp4.545,97. Pada musim tanam II produksi terbesar diperoleh pada panen pertama sebesar $101,61 \mathrm{~kg}$ dengan harga $\mathrm{Rp} 4.589,29 / \mathrm{kg}$ dan terendah pada panen terakhir sebesar $23,13 \mathrm{~kg}$ dengan harga Rp4.692,31/kg. Total produksi musim tanam II sebesar 380,54kg dengan harga Rp4.642,86. Hasil penelitian ini selaras dengan penelitian Nisa, Haryono, dan Murniati (2018) dimana frekuensi panen tidak selalu sama jumlah produksi tiap panennya.

Pendapatan usahatani diketahui melalui pengurangan antara penerimaan dan biaya. Berdasarkan hasil penelitian diperoleh rata-rata penerimaan usahatani pada musim tanam pertama atas biaya tunai sebesar Rp1.344.073,70 dan penerimaan pada musim tanam kedua sebesar Rp1.193.198,65. Hasil penerimaan pada musim tanam I lebih besar dari pada musim tanam II, hal
Tabel 4. Rata-rata produksi, biaya, dan penerimaan petani pola tanam I.

\begin{tabular}{|c|c|c|}
\hline Uraian & $\begin{array}{l}\text { Buncis (I) } \\
\text { Rp/0,08ha }\end{array}$ & $\begin{array}{l}\text { Buncis (II) } \\
\text { Rp/0,08ha }\end{array}$ \\
\hline Produksi & 431,61 & 380,54 \\
\hline Harga & $4.545,97$ & $4.642,86$ \\
\hline Penerimaan & $1.962 .098,34$ & $1.766 .772,96$ \\
\hline \multicolumn{3}{|l|}{ Biaya Produksi } \\
\hline a. Tunai & & \\
\hline Pupuk Urea & $49.354,84$ & $50.357,14$ \\
\hline Pupuk Phonska & $41.731,00$ & $41.761,22$ \\
\hline Pupuk kandang & $258.029,78$ & $239.318,18$ \\
\hline Suprasit & $21.852,24$ & $20.928,57$ \\
\hline Sidametrin & $24.599,38$ & $22.882,65$ \\
\hline Curakron & $22.151,93$ & $26.630,10$ \\
\hline TKLK & $200.305,26$ & 171.696 .43 \\
\hline Tota biaya tunai & $618.024,64$ & 573.574 .30 \\
\hline \multicolumn{3}{|l|}{$\begin{array}{ll}\text { b. } & \text { Diperhitungkan }\end{array}$} \\
\hline Benih & $35.110,65$ & $32.305,00$ \\
\hline TKDK & $891.129,44$ & $732.857,14$ \\
\hline Penyusutan alat & $49.109,18$ & $49.109,18$ \\
\hline Pupuk (milik sendiri) & $243.003,58$ & $250.941,18$ \\
\hline Sewa lahan & $72.000,00$ & $72.000,00$ \\
\hline Total biaya diperhitungkan & $1.290 .352,85$ & $1.163 .426,79$ \\
\hline Total biaya & $1.908 .377,49$ & $1.137 .212,50$ \\
\hline Pendapatan atas biaya tunai & $1.344 .073,70$ & $1.193 .198,65$ \\
\hline Pendapatan atas biaya total & $53.720,85$ & $55.986,15$ \\
\hline$\overline{\mathrm{R} / \mathrm{C} \text { Ratio atas biaya tunai }}$ & 3,17 & 3,08 \\
\hline $\mathrm{R} / \mathrm{C}$ Ratio atas biaya total & 1,03 & 1,03 \\
\hline
\end{tabular}

ini disebabkan rendahnya produksi di musim tanam kedua sehingga berpengaruh pada penerimaan petani.

\section{Pola Tanam II (Buncis - Kacang panjang)}

Pada pola tanam II, petani menanam tanaman jenis buncis (musim tanam I) pada bulan Setember November. Setelah itu, petani melanjutkan. penanaman pada lahan yang sama dengan jenis tanaman kacang panjang pada bulan Desember hingga April.

Penggunaan benih pada pola tanam II serupa dengan pola tanam I yang diperbanyak dari tanaman hasil panen dan digunakan pada 3-4 kali musim tanam. Harga benih yang terdapat di lokasi penelitian sebesar $\mathrm{Rp} 140.000,00 / \mathrm{Kg}$ dan benih kacang panjang sebesar Rp150.000,00/kg. Biaya penggunaan benih musim tanaman I sebesar dengan biaya Rp39.760,00/kg/0,07ha dan musim tanam II Rp52.535,00/kg/0,07ha.

Pestisida yang digunakan pada pola tanam II memiliki merk dagang yang sama dengan pola tanam I, yaitu: suprasit, curakron dan sidametrin. Total biaya pestisida untuk musim tanam I sebesar Rp65.382,72 sedangkan untuk musim tanam II sebesar Rp43.345,68. 
Penggunaan pupuk kandang pada pola tanam II memiliki jumlah yang lebih banyak karena sangat bermanfaat bagi tanaman. Pernyataan ini selaras dengan peneletian Setiani, Zakaria dan Adawiyah (2015) yang menyatakan pupuk organik memiliki banyak manfaat, diantaranya meningkatkan kesuburan lahan dan mencegah degradasi. Biaya tunai pupuk musim tanam I sebesar Rp343.285,19 sedangkan pada musim tanam II biaya tunai pupuk sebesar Rp331.436,54.

Biaya tenaga kerja yang dikeluarkan pada budidaya usahatani pola tanam II terdiri dari biaya tenaga kerja dalam keluarga (TKDK) dan luar keluarga (TKLK), baik pria atau wanita biaya yang dikeluarkan diukur setara dengan Hari Kerja Pria

Tabel 5. Penggunaan sarana dan biaya produksi (Pola tanam II musim tanam I).

\begin{tabular}{lrrr}
\hline \multirow{2}{*}{ Uraian } & \multicolumn{3}{c}{ Musim Tanam I } \\
\cline { 2 - 4 } & Jumlah & \multicolumn{1}{c}{ Harga } & \multicolumn{1}{c}{ Biaya } \\
\hline Benih & 2,80 & $14.200,00$ & $39.760,00$ \\
Pupuk: & & & \\
$\quad$ Kandang (tunai) & 325,00 & 677,78 & $220.277,78$ \\
Kandang (non tunai) & 450,00 & 677,78 & $305.000,00$ \\
Urea & 25,33 & $2.700,00$ & $68.400,00$ \\
Phonska & 21,56 & $2.533,33$ & $54.607,41$ \\
\hline Pestisida: & & & \\
Suprasit & 0,12 & $192.222,22$ & $23.493,83$ \\
Sidametrin & 0,08 & $283.333,33$ & $22.037,04$ \\
Curakron & 0,07 & $297.777,78$ & $19.851,85$ \\
\hline Peralatan: & & & \\
$\quad$ Golok & & & $15.555,56$ \\
Cangkul & & & $23.611,11$ \\
Gembor & & & $23.055,56$ \\
Sprayer & & & $12.222,22$ \\
Lanjaran bambu & & & $40.185,19$ \\
Arit & & & $7.666,67$ \\
\hline
\end{tabular}

Tabel 6. Penggunaan sarana dan biaya produksi (Pola tanam II musim tanam I).

\begin{tabular}{lrrr}
\hline \multirow{2}{*}{ Uraian } & \multicolumn{3}{c}{ Musim Tanam II } \\
\cline { 2 - 4 } & Jumlah & \multicolumn{1}{c}{ Harga } & \multicolumn{1}{c}{ Biaya } \\
\hline Benih & 3,46 & $15.200,00$ & $52.535,00$ \\
Pupuk & & & \\
Kandang (tunai) & 375,00 & 655,56 & $245.833,33$ \\
Kandang (non tunai) & 560,00 & 655,56 & $367.111,11$ \\
Urea & 23,33 & $2.944,44$ & $68.703,70$ \\
Sp36 & 13,89 & $4.944,44$ & $68.672,84$ \\
\hline Pestisida & & & \\
Suprasit & 0,12 & $192.222,22$ & $23.493,83$ \\
Curakron & 0,07 & $297.777,78$ & $19.851,85$ \\
\hline Peralatan & & & \\
Golok & & & $15.555,56$ \\
Cangkul & & & $23.611,11$ \\
Gembor & & & $23.055,56$ \\
Sprayer & & & $12.222,22$ \\
Lanjaran bambu & & & $40.185,19$ \\
Arit & & & $7.666,67$ \\
\hline
\end{tabular}

(HKP). Biaya tenaga kerja musim tanam I sebesar 5,44 HKP dan musim tanam II sebesar 4,25 HKP. Penggunaan tenaga kerja pada usahatani lebih banyak tercurah ke dalam proses pengolahan tanah yang akan berdampak pada hasil produksi usahatani.

Total produksi buncis pada musim tanam I sebesar 407,22kg dengan harga Rp4.765,93/kg sedangkan produksi usahatani kacang panjang memperoleh total produksi panen sebesar $766,67 \mathrm{~kg}$ dengan harga Rp2.582,33/kg. Berdasarkan hasil penelitian diperoleh rata-rata penerimaan usahatani pada musim tanam pertama atas biaya tunai sebesar

Tabel 7. Penggunaan tenaga kerja pada musim tanam I dan II pola tanam II.

\begin{tabular}{lcccccc}
\hline \multirow{2}{*}{ Jenis Kegiatan } & \multicolumn{6}{c}{ Pola Tanam I } \\
\cline { 2 - 7 } & \multicolumn{4}{c}{ MT I } & \multicolumn{4}{c}{ MT II } \\
\cline { 2 - 7 } & DK & LK & Total & DK & LK & Total \\
\hline Pengolahan lahan & 3,86 & 1,58 & 5,44 & 2,08 & 2,17 & 4,25 \\
Penanaman benih & 1,06 & 0,00 & 1,06 & 1,06 & 0,00 & 1,06 \\
Pemupukan & 0,89 & 0,00 & 0,89 & 0,89 & 0,00 & 0,89 \\
Penyulaman & 1,97 & 0,00 & 1,97 & 1,42 & 0,00 & 1,42 \\
Penyiangan gulma & 1,38 & 0,00 & 1,38 & 1,38 & 0,00 & 1,38 \\
Pengendalian HPT & 1,81 & 0,00 & 1,81 & 1,81 & 0,00 & 1,81 \\
Panen & 4,03 & 0,63 & 4,03 & 3,01 & 0,49 & 3,50 \\
Pasca Panen & 1,18 & 0,00 & 1,18 & 1,18 & 0,00 & 1,18 \\
\hline Jumlah & 16,17 & 1,58 & 17,5 & 12,82 & 2,65 & 15,47 \\
\hline
\end{tabular}

Tabel 8. Rata-rata produksi, biaya, dan penerimaan petani pola tanam II.

\begin{tabular}{|c|c|c|}
\hline Uraian & $\begin{array}{c}\text { Buncis } \\
\mathrm{Rp} / 0,07 \mathrm{ha}\end{array}$ & $\begin{array}{l}\text { Kc panjang } \\
\mathrm{Rp} / 0,07 \mathrm{ha}\end{array}$ \\
\hline Produksi & 407,22 & 766,67 \\
\hline Harga & $4.765,93$ & $2.582,33$ \\
\hline Penerimaan & $1.940 .790,95$ & $1.979 .782,92$ \\
\hline
\end{tabular}

Biaya Produksi

\begin{tabular}{lrr} 
c. Tupuk Urea & & \\
Pupuk Phonska & $68.400,00$ & $68.703,70$ \\
Pupuk kandang & $54.607,41$ & 0,00 \\
Suprasit & $220.277,78$ & $245.833,33$ \\
Sidametrin & $23.493,83$ & $68.672,84$ \\
Curakron & $22.037,04$ & $20.222,22$ \\
TKLK & $19.851,85$ & $29.555,56$ \\
Tota biaya tunai & $89.411,76$ & $159.166,67$ \\
\hline d. Diperhitungkan & $498.079,67$ & $592.154,32$ \\
Benih & $39.760,00$ & $52.535,00$ \\
TKDK & $912.941,18$ & $769.166,67$ \\
Penyusutan alat & $61.151,15$ & $61.151,15$ \\
Pupuk (milik sendiri) & $305.000,00$ & $367.111,11$ \\
Sewa lahan & $62.000,00$ & $62.000,00$ \\
Total biaya diperhitungkan & $1.380 .852,32$ & $1.311 .963,93$ \\
Total biaya & $1.878 .931,99$ & $1.904 .118,25$ \\
\hline Pendapatan atas biaya tunai & $1.442 .711,28$ & $1.387 .628,60$ \\
Pendapatan atas biaya total & $61.858,96$ & $75.664,67$ \\
\hline R/C Ratio atas biaya tunai & 3,90 & 3,34 \\
R/C Ratio atas biaya total & 1,03 & 1,04 \\
\hline
\end{tabular}


Rp1.442.711,28 dan penerimaan pada musim tanam kedua sebesar Rp1.387.628,60 dengan biaya tunai sebesar Rp498.079,67 untuk musim tanam pertama dan sebesar Rp592.154,32 untuk musim tanam kedua.

\section{Pendapatan Usahatani Lainnya}

Beberapa petani memiliki usahatani lainnya yang dibudidayakan di lahan perkebunan dan pekarangan. Rata-rata luas lahan perkebunan yang dimiliki petani pola tanam I sebesar 0,03 ha dan pola tanam II 0,02ha. Tanaman yang dibudidayakan pada lahan perkebunan, yaitu: pepaya, kakao, kopi, singkong, cabai dan pisang. Pada lahan pekarangan, rata-rata luas yang dimiliki petani pola tanam I sebesar 0,03 ha, dan pola tanam II sebesar 0,01ha dengan jenis tanaman yang dibudidayakan adalah rampai, sawi, kacang tanah dan ternak kambing atau sapi. Rata-rata total pendapatan per tahun untuk pola tanam I sebesar Rp8.116.129,03 sedangkan pola tanam II diperoleh nilai sebesar Rp3.755.555,56.

\section{Pendapatan Off Farm}

Responden juga memperoleh peghasilan tambahan melalui pekerjaan off farm seperti, buruh di bidang pertanian, sebagai pengumpul hasil usahatani dan pengolahan hasil pertanian. Rata-rata pendapatan yang diperoleh dari pekerjaan off farm pada pola tanam I sebesar Rp627.419,00/tahun, sedangkan pada pola tanam II sebesar Rp505.555,56/tahun.

\section{Pendapatan Non Farm}

Pekerjaan diluar kegiatan pertanian (non farm) dilakukan petani untuk memperoleh penghasilan tambahan seperti pedagang, buruh bangunan dan pekerjaan non pertanian lainnya (jasa pijat, pegawai/karyawan). Berdasarkan hasil penelitian besarnya perolehan pendapatan pekerjaan non farm pada pola tanam I sebesar Rp12.036.363,64 sedangkan pada pola tanam II sebesar Rp6.750.000,00. Kontribusi pendapatan non farm berperan cukup besar dalam memenuhi kebutuhan, pernyataan ini selaras dengan penelitian Sari, Haryono, dan Rosanti (2014) yang menyatakan pendapatan non farm sangat dibutuhkan petani agar dapat menambah aset petani.

\section{Pendapatan Rumah Tangga}

Sumber pendapatan rumah tangga pertanian di Kelurahan Kedaung, Kecamatan Kemiling, Kota Bandar Lampung diperoleh dari pendapatan usahatani atau budidaya (on farm), usahatani di luar kegiatan usahatani (off farm), dan usaha non pertanian (non farm). Jumlah rata-rata pendapatan per tahun diperoleh melalui penjumlahan sumber pendapatan yang disajikan pada Tabel 9 .

Sumber pendapatan petani dari kegiatan on farm memberikan persentase pola tanam I sebesar 45,80 persen dan pola tanam II sebesar 47,58 persen, untuk pekerjaan off farm pada pola tanam I diperoleh persentase sebesar 2,70 persen dan pada pola tanam II sebesar 3,65 persen. Pekerjaan non farm memiliki persentase pola tanam I sebesar 51,84 persen dan pada pola tanam II 48,76 persen. Berdasarkan hasil persentase pendapatan dapat diketahui bahwa masih terdapat pekerjaan di bidang pertanian di tengah pergeseran tenaga kerja di sektor pertanian menuju sektor non pertanian.

Rata-rata pendapatan per tahun yang diperoleh petani di Kelurahan Kedaung, Kecamatan Kemiling, Kota Bandar Lampung pada pola tanam I sebesar Rp23.217.784,40 dan pada pola tanam II sebesar Rp13.841.450,00.

\section{Tingkat Kesejahteraan}

Kemiskinan dan kesejahteraan merupakan keadaan yang berkaitan karena penurunan tingkat kemiskinan, maka akan berpengaruh pada tingkat kesejahteraan. Tingkat kesejahteraan rumah tangga pertanian di Kelurahan Kedaung diukur dengan indikator kesejahteraan BPS (2014) dengan kategori tidak sejahtera (7-11), belum sejahtera (12-16) dan sejahtera (17-21). Indikator kependudukan menjelaskan jumlah anggota keluarga yang menggambarkan kemampuan keluarga untuk kebutuhan. Indikator kesehatan dan gizi bertujuan mengetahui pengetahuan

Tabel 9. Struktur pendapatan rumah tangga di Kelurahan Kedaung, Kecamatan Kemiling, Kota Bandar Lampung.

\begin{tabular}{|c|c|c|c|}
\hline \multirow{2}{*}{\multicolumn{2}{|c|}{ Jenis pekerjaan }} & \multicolumn{2}{|c|}{ Pendapatan (Rp) } \\
\hline & & Pola Tanam I & Pola Tanam II \\
\hline \multicolumn{4}{|c|}{ On Farm } \\
\hline a) & Usahatani utama & $2.537 .272,35$ & $2.830 .339,88$ \\
\hline b) & Usahatani lainnya & $8.116 .129,03$ & $3.755 .555,56$ \\
\hline \multicolumn{4}{|c|}{ Off Farm } \\
\hline a) & Buruh tani & $156.451,61$ & $505.555,56$ \\
\hline b) & Pengumpul & $354.838,71$ & 0,00 \\
\hline & Pengolahan usatan & $116.129,03$ & 0,00 \\
\hline \multicolumn{4}{|c|}{ Non Farm } \\
\hline a) & Bangunan & $2.536 .363,64$ & $2.250 .000,00$ \\
\hline b) & Pedagang & $5.166 .666,67$ & 0,00 \\
\hline & Lain-lain & $4.333 .333,33$ & $4.500 .000,00$ \\
\hline Jun & lah & $23.217 .784,40$ & $13.841 .450,00$ \\
\hline
\end{tabular}


pengetahuan tentang gizi yang diperlukan untuk menjaga kesehatan. Indikator pendidikan bertujuan mengetahui tingkat pendidikan setiap anggota keluarga petani. Indikator ketenagakerjaan menjelaskan lama waktu bekerja. Indikator taraf dan pola konsumsi menjelaskan kesanggupan responden dalam mengkonsumsi pangan yang sesuai kecukupan gizi yang dianjurkan. Indikator perumahan menggambarkan fisik dan hunian sebagai tempat tinggal. Indikator sosial menjelaskan aktifitas responden terhadap kegiatan sosial dan waktu untuk berwisata serta kemampuan penggunaan teknologi.

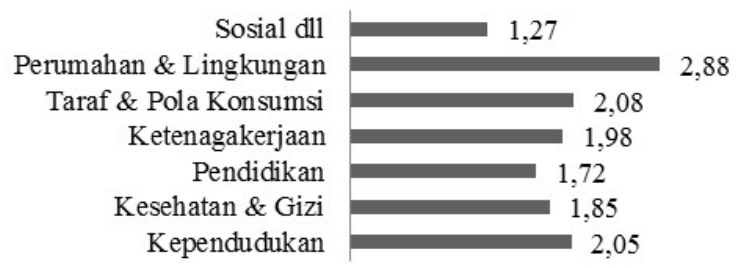

Gambar 1: Skor tingkat kesejahteraan BPS 2014.

Berdasarkan data dari tujuh indikator BPS (2014) terdapat perbedaan skor pada masing-masing indikator sehingga diperoleh nilai dengan skor yang beragam yang disajikan pada Gambar 1 . Gambar 1 menjelaskan bahwa skor terendah diperoleh pada indikator sosial dengan nilai 1,3 yang menjelaskan kurangnya kegiatan sosial petani sehingga memberikan skor yang rendah pada indikator sosial.

Kategori yang diperoleh dari skor indikator dibedakan atas 3 yaitu: Kurang (1-1,6), cukup (1,72,3) dan baik (2,4-3). Gambar 1 menjelaskan bahwa indikator sosial memiliki skor terendah $(1,3)$ yang berada pada kategori kurang. Berdasarkan nilai dari masing-masing indikator dapat diketahui kategori pentahapan kesejahteraan. Pentahapan kesejahteraan rumah tangga pertanian di Kelurahan Kedaung, Kecamatan Kemiling, Kota Bandar Lampung disajikan pada Tabel 10.

Tabel. 10. Jumlah responden berdasarkan tingkat kesejahteraan dengan indikator BPS.

\begin{tabular}{lrrr}
\hline \multirow{2}{*}{ Kategori } & \multicolumn{3}{c}{ Rumah Tangga } \\
\cline { 2 - 4 } & $\begin{array}{c}\text { Jumlah } \\
\text { (jiwa) }\end{array}$ & Skor & $\begin{array}{c}\text { Persentase } \\
(\%)\end{array}$ \\
\hline Tidak Sejahtera & 0 & $7-11$ & 0 \\
Belum Sejahtera & 38 & $12-16$ & 95 \\
Sejahtera & 2 & $17-21$ & 5 \\
\hline Jumlah & 40 & & 100 \\
\hline
\end{tabular}

Tabel 10 menjelaskan bahwa dari analisis tingkat kesejahteraan yang ditentukan melalui indikator BPS (2014), sebanyak 95 persen atau 38 rumah tangga pertanian di Kelurahan Kedaung, Kecamatan kemiling, Kota Bandar Lampung berada pada rentang skor 12-16, yang dikategorikan dalam indikator belum sejahtera. Faktor yang menyebabkan keadaan tersebut yaitu rendahnya skor indikator sosial, pendidikan dan kesehatan sehingga pola hidup yang berkaitan dengan indikator-indikator tersebut harus diperbaiki

\section{KESIMPULAN}

Pendapatan usaha tani utama rumah tangga pertanian di Kelurahan Kedaung, Kecamatan Kemiling, Kota Bandar Lampung pada pola tanam I sebesar Rp2.537.872,35 sedangkan pada pola tanam sebesar II Rp2.830.339,88. Pendapatan rumah tangga per tahun pada pola tanam I Rp23.317.784,40 dan pola tanam II Rp13.841.450,10. Sebanyak 95 persen rumah tangga pertanian di Kelurahan Kedaung, Kecamatan Kemiling, Kota Bandar Lampung berada pada kategori belum sejahtera.

\section{DAFTAR PUSTAKA}

Badan Pusat Statistik. 2014. Indikator Kesejahteraan Rakyat - Welfare Indicator (2014). https :// bps.go.id / publication / indikator - kesejahteraan-rakyat [21 Januari 2019].

Badan Pusat Statistik. 2016. Kota Bandar Lampung Dalam Angka. https: // bps.go.id / publication / Kota - Bandar Lampung-dalam - angka [21 Januari 2019].

Badan Pusat Statistik]. 2017. Provinsi Lampung Dalam Angka. https: // bps.go.id / publication / Provinsi - Lampung - dalam angka [21 Januari 2019].

Mantra IB. 2003. Demografi Umum Edisi Kedua. Pustaka Pelajar. Yogyakarta.

Nisa UC, Haryono D, dan Murniati K. 2018. Pendapatan usahatani cabai merah di Kecamatan Kalianda Kabupaten Lampung Selatan. JIIA, 6 (2): 150-151. [19 Januari 2019].

Sari DK, Haryono D, dan Rosyanti N. 2014. Analisis pendapatan dan tingkat kesejahteraan rumah tanggga petani jagung di Kecamatan Natar Kabupaten Lampung Selatan. JIIA, 2 (1): 67-69. [19 Januari 2019]. 
JIIA, VOLUME 8 No 2, MEI 2020

Setiani N, Zakaria WA, dan Adawiyah R. 2015. Analisis keuntungan usahatani antar pola tanam di lahan sawah Desa Tatakarya Kecamatan Abung Surakrta Kabupaten Lampung Utara. JIIA, 3 (2): 125-127. [19 Januari 2019].

Soekartawi. 1994. Teori Ekonomi Produksi ; Dengan Pokok Bahasan Analisis Fungsi
Cobb-Douglas. Raja Grafindo Persada. Jakarta.

Sugiarto, Siagian D, Sunarto LS, dan Oetomo DS. 2003. Teknik Sampling. Gramedia Pustaka Utama. Jakarta.

Sugiyono. 2010. Metode Penelitian Pendidikan Pendekatan Kuantitatif, Kualitatif, dan $R \& D$. Alfabeta. Bandung. 